Journal of Social and Development Sciences

Vol. 5, No. 1, pp. 14-25, Mar 2014 (ISSN 2221-1152)

\title{
Micro-Credit in Conventional Banking: Would Islamic Banking be the Golden Age for Entrepreneurs? -The Mauritius Case Study
}

\author{
Rajendra Parsad GUNPUTH \\ University of Mauritius, Mauritius \\ rpgunput@uom.ac.mu
}

\begin{abstract}
The broad aim of this paper is to make an analogy between conventional banks and Islamic banking in micro-credit and the incentives they may provide for entrepreneurs and small and medium enterprises (SMEs) in a Mauritian perspective? Indeed, in Mauritius traditional or conventional banks are more and more reluctant to give loans to entrepreneurs who are considered as high risk investors (their fragile entrepreneurs may collapse unexpectedly) despite they create jobs and employment. In contrast, in most Islamic countries Islamic banks allow businessmen and investors among others to have loans without interest (or riba) according to sha'ria compliants and tailor made Islamic contracts (mudabara and musarakha) to support their innovations and proposals. Despite Islamic banking is at its burgeoning state it has expanded considerably in most Islamic and Arab countries. Would Islamic banks uproot conventional banks irrespective it is in Islamic countries or Western countries? This paper therefore adds to an already abundant literature on the subject-matter but it enlightens a central issue: would Islamic banking, sha'ria law and Islamic economies be the golden age for entrepreneurs and SMEs in Mauritius and worldwide?
\end{abstract}

Keywords: Islamic banking, shar'ia, riba, ijara, mudabara and musarakha, Mauritius

\section{Introduction}

Mauritius, located in the Indian Ocean with its 1.3 million inhabitants, and its 92,000 small units are one of the driving forces of the economy of the island creating jobs and employment $(210,000)$, eradicating poverty and is a good support for the socio-economic development of the island especially when the price sugar has fallen down. The Mauritian legislator has passed a number of legislations and policies ${ }^{1}$ to support SMEs. The total value added generated by SMEs is estimated at Rs 45 million contributing to the gross domestic product. However, despite these figures, it has been found that conventional banks are still very reluctant to give loans to entrepreneurs and SMEs for them to start business. Traditional banks give loans to finance entrepreneurs and SMEs but how micro-finance works in Islamic banking? Originated from a number of surahs of the Holy Qur'an, the principal source of Islamic law, revealed through its Prophet Muhammad (pbuh) and hadiths mention business and trade and how they should be financed and managed by all Islamic employees who trust in their faith. In contrast, a number of facilities provided by conventional banks such as loans with interests are strictly prohibited by shar'ia law and Islamic banking and financing such that it meets the expectations of all Muslim community providing islamically acceptable financing modes, loans without interest (riba) in all its forms, Profit and Loss Sharing (PLS) methods (mudaraba), equitable and fair distribution of profits according to a predetermined ratio, profit returns for assuming risk undertaken, autonomous and independent entrepreneurs in the management of the affairs of their small and medium enterprises, microcredit facilities such that Islamic banks play a role of partner (shirkah) with its entrepreneurs in a very productive-direct investment. Since the mid-1940s, businessmen and investors worldwide discovered a paradigm shift from conventional banks to Islamic banks especially in most Islamic countries. How is it perceived when conventional banks are so deeply rooted in most non-Islamic countries? Islamic banking and Islamic banks are supporting entrepreneurs (Bangladesh, Pakistan and Malaysia) to take

\footnotetext{
${ }^{1}$ The Borrower Protection Act 2007, Companies Act 2001, Consumer Protection (Price and Supplies Control) Act, Cooperative Societies Act 1976, The Investment Promotion Act 2000, Business Registration Act 2002, Small Enterprises and Handicraft Development Authority Act 2005 (SEHDA 2005), Copyright Act 1997, Electronic Transactions Act 2000, Information and Communications Technologies Act 2001, Protection Against Unfair Practices (Industry Property Rights ) Act 2002; Patents, Industrial, Designs and Trademarks Act 2002
} 
loans without interest on a PLS investment. Actually, millions of people in Islamic countries are relying on this type of financing to survive. After having cleared some technical issues on Islamic financial and business contracts (ijara, murabaha, bai'salalm, bai'muajjal, istisanaa, qard hasan), this study will certainly allow entrepreneurs in non-Muslim countries (Mauritius, India, Singapore, France, South Africa) to better understand Islamic concepts and practices, and facilities which are afforded by Islamic banking and new modes of financing with probably a real departure from conventional banks.

However, the main objectives of this paper are to understand the concepts and the blessings of sha'ria law to SMEs. Whether Islamic banks would probably uproot conventional banks worldwide so that entrepreneurs and SMEs have an alternate route to do business, trade and investment through Islamic banking? The aims and objectives of this paper are focused essentially on the concepts of entrepreneurship and social contracts in Islamic banking and what shall come out of this paper would probably encourage any entrepreneur to have financial support from Islamic banking which blooms even in a period of crisis. The gist of this paper is how entrepreneurs in Islamic countries could obtain funds without interest ( $r i b a$ ) to purchase goods and assets to run their trade and business? Finally, what shall come out of this paper must certainly encourage young entrepreneurs to understand the legal and social concepts of entrepreneurship provided by Islamic banks and shar'ia law and the advantages they would probably benefit from it. After an introduction (-I-), the structure of the paper follows a background to SMEs in conventional banking (II), a traditional literature review (-III-) to enlighten us on eminent experts views followed by an overview (-IV-) on the subject matter, a research methodology (-V-) will eventually pave the way for some concluding results (-VI-), a conclusion (VII-) will close this paper followed by some references (-VIII-).

Background to Conventional-Islamic Micro-Credits and Rationale of the Study: Though SMEs create jobs and employment traditional banks are more and more reluctant to fund entrepreneurs and SMEs whilst Islamic banks provide social contracts without loans but on the principle of PLS. In contrast, this paradigm shift from conventional banks to Islamic banks will definitely take some time. Worst, doing business are getting more expensive. Consequently entrepreneurs may be discouraged to open business. Would young and modern entrepreneurs in non-Islamic welcome Islamic banking and what is the cost to pay if they abide to shar'ia law? Despite the fact that there is a quite a number of legal materials on Islamic banking and finance authored by eminent scholars (infra) little is known about this emerging sector in most non-Islamic countries and especially how it may be beneficial to entrepreneurs who, inter alia, contribute to the welfare of a nation by improving the Gross Domestic Product (GDP). Probably Islamic finance and its legal and social contract model suffered from an absence of very high quality media and it may account for this. However, would Islamic banking survive in non-Islamic countries and to what extent they may cohabit with conventional banks and other well-implemented legislations borrowed and inspired form French Civil Law or Common Law are questions which are very often overlooked or ignored? Whatsoever, conventional banks are perceived as business institutions while Islamic banking tries to reconcile PLS first corporate social responsibility first into their aims and objectives coupled with material and spiritual satisfaction to all Muslim believers without any exception.

Legal and social aspects of entrepreneurship are not well understood in the relation Islamic bankingconventional or traditional banking. Indeed, based on Islamic or shar'ia law and though Islamic banking is free-interest banking nonetheless this model is still unpopular in non-Islamic countries while there may be some facilities that it may provide to entrepreneurs. Indeed, how Islamic banking works on the basis of shar'ia law is easy to understand but is it as easy as it pretends for entrepreneurs to have access to it especially in non-Islamic countries (for example India, Mauritius, Singapore or South Africa)? A sound and plausible rationale to this question is that most entrepreneurs are used to traditional banks, loans and mortgages with its traditional fixed and floating charges while Islamic banking and financing is more or less than a commercial partner with entrepreneurs and which more oriented in PLS arrangements. Furthermore, in Islamic or non-Islamic countries whenever there is Islamic finance and conventional banks there is also a sort of harmonization between Civil Law and Islamic (shar'ia) law. Of divine inspiration, business and trade have therefore a different concept in Islamic law or shar'ia law such that what is allowed in conventional banking such as loans with interest is strictly prohibited in Islamic law (haram) and what is allowed in Islamic banking, as a partner in the transaction with entrepreneurs, such as PLS is still unknown oi inacceptable in conventional banking. Whatsoever, out of the two systems of financing would entrepreneurs 
benefit from one system or another or both? Facts and figures (infra) reveal to what extent Islamic banking is a booming industry in our business world today. Most Islamic countries (Bahrain, Malaysia, and Pakistan) are really benefitting from this type of fundings as well and Islamic finance has been very successful in Bangladesh especially for women entrepreneurs. Based on the principle of 'innovate or die' microfinance in Bangladesh has been able to finance women entrepreneurs creating jobs, opportunities for one and all, fight against poverty and contributing to the GDP of the dying economy of this country.

\section{Literature Review}

In business entrepreneurship there is nothing as revolutionary as Islamic banking and its modes of finance. According to sha'ria law there is a social contract between men and God and in any way there shall be interest or riba in any transaction irrespective it is between banks and its clients or between men. Furthermore, musharaka (joint venture) and mudharaba (financing) are tailor-made Islamic contracts which undeniably provide protection against interest rate (murabaha or mark-up). As stated, the main source of Islamic banking and finance is shari'ah law and contracts in addition to hadiths in the most prophetic tradition. The superiority of a loan (qard hasan) without interest (riba) over charity is also based on a hadith of Prophet Muhammad (pbuh):

"O Jibril, why is a loan rewarded more than charity? The angel replied, 'Because a person may ask for charity when he does not need it, but the borrower only borrows in case of desire need"'.

In rural areas (in Bangladesh around 40,000 women are selling telephone services and Nobel prize winner Muhammad Yunnus advocated lengthily on the importance of the Grameen Type Microcredit model) SMEs are creating employment in most slums whereas in urban zones ('urban poverty') entrepreneurs may enter a particular market (motorcycle repair workshops, bakery) and trade where large firms fear to invest (printing for example) thus reducing the mobility of workers from one zone to another ${ }^{2}$. A very large number of eminent authors have authored books, research articles and reports on Islamic banking concluding their assessment that in the overall Islamic banking was more efficient than conventional banks (Iqbal and Molyneux, 2005). Nonetheless, there are still some conflicting views and divergent opinions about riba because there are PLS between lender and borrower instead (khan and Mirakhor, 1987). At least from the 19th century onward, certain observers have viewed Islam as a religion that discourages entrepreneurship by fostering fatalism, conformism, and conservatism but Islamism; which emerged through the work of Sayyid Abdul-Ala Mawdudi and Sayyid Qutb and Muhammad Baqir al-Sadr; generally agrees that Islam encourages entrepreneurship (Kuran³, 2008).

In fact, some authors (infra) have found that Islamic banking could complement conventional banks and thereby help diversify systemic risks: in conventional banks the entrepreneur or any borrower bears all risks and is liable for mismanagement while in Islamic banking both bank(s) and entrepreneur(s) share the rewards and failure. In many developing countries risk sharing might allow entrepreneurs with little savings to undertake projects they could not contemplate in an environment where all the risk lies on them. According to Khan and Mirakhor (1985) PLS arrangement eliminates the fixed cost of capital and may therefore tend to raise overall investment. In conventional banking, the creditworthiness of the borrower is the main determinant of the lending decision, banks are interested in the interest and principal on the loan while in Islamic banking, because profits and losses are shared, banks will receive a return only if a project is successful such that Islamic banks are more prone to finance sound projects, even if the entrepreneur has no credit history (Imam and Kpodar, 2010). However, the two respected authors referred to Cihak and Hesse (2008) and the research they have achieved demonstrating to what extent Islamic banks tend to be less stable when operating on a large scale, suggesting that:

"Under certain conditions, a growing Islamic banking sector might not be beneficial for economic growth if it weakens financial stability in countries where a proper prudential regulation is lacking. It is probably fair to

\footnotetext{
${ }^{2}$ Gunputh (20110. Enhancing the Entrepreneurial Minds in the Informal Sector -The Mauritian SMEs Case Study-. Journal MERI, India

${ }^{3}$ Kuran T. (2008). The scale of entrepreneurship in middle eastern history: inhibitive roles of Islamic institutions, ERID Working Paper Number 10, Duke University, Economic Research Initiatives at Duke working Papers Series, March 2008
} 
say that the benefits in having banking systems that are diversified and include Islamic banks as a complement to conventional banks, is likely to be helpful for financial stability".

Now, as far as Islamic issues are concerned, as mentioned earlier, riba is prohibited such that according to the Prophet Muhammad (pbuh): "riba has seventy segments, the least serious being equivalent to a man committing adultery with his own mother". The sin of all Islamic banking is traditional interest and riba is strictly forbidden. "Trade is like usury. God allowed trading and forbid riba" (Quran 2:275).With the advent of Islam Islamic banking have been so successful that even conventional banks are offering shar'iah compliant financial products (Abou-Gabal and Klinger, 2011). To quote Janachi (1995):

"Islamic banks have a major responsibility to shoulder all the staff of such banks and customers dealing with them must be reformed Islamically and act within the framework of an Islamic formula, so that any person approaching an Islamic bank should be given the impression that he is entering a sacred place to perform a religious ritual, that is the use and employment of capital for what is acceptable and satisfactory to God. The staff in an Islamic bank should, throughout their lives, be conducting in the Islamic way, whether at work or at leisure. Muslims who truly believe in their religion have a duty to prove, through their efforts in backing and supporting Islamic banks and financial institutions, that the Islamic economic system is an integral part of Islam and is indeed for all times through making legitimate and Halal profits".

There is also the reverse of the medal. Many Islamic banking scholars (Chapra, 1982 and Chapra, 1985; Ahmad, 2000, Khan \& Mirakhor, 1987, Iqbal and Mirakhor (1986) have demonstrated that Islamic banks perform mostly the same functions as conventional banks but they do so in distinctly different ways. In one of his research papers, a very respected scholar (Asyraf, 2011) explained that the prevailing practice of interest in the conventional banking system involves injustice to the borrowers since the interest on their loans has to be paid irrespective of the outcomes of their businesses, similarly, interest contracts (infra) can be unjust to the lenders, especially when their returns on deposits that the banks channel to entrepreneurs are not commensurate with the actual performance of the investments. However, there is a strong analogy between conventional and Islamic banks: banks very often discriminate between the poor and the rich though Islamic and sha'ria law prohibits discrimination between Muslims. Thus, it can be said openly that:

"Apparently, it is a matter of pleasure that global volume of Islamic finance industry has crossed \$1.3trillion approximately, which is, definitely, providing the best and compatible sources of finance with interest free modes. According to a careful estimate, there are more than 2000 Islamic Financial Institutions offering Islamic Banking, Islamic Insurance (Takaful), Islamic Funds, Mudaraba, Islamic Bonds (sukuk), Islamic Microfinance and some other institutions actively providing Islamic financial services on different modes in adherence of Shari'a principles of Islamic Finance. If we look into the market share of above mentioned institutions, we get shocked and depressed for a while with the fact that Islamic Banking and Finance has been nearly confined to the rich people and as per the ideology of capitalism, the profit urge has captured the Islamic Financial Industry and discriminated against the underprivileged, leaving them deprived of Islamic financial services. In view of these facts, it should be said that commercialism has captured Islamic finance institutions in such a way that business with and financing to the poor have slipped from their agenda ${ }^{\prime \prime}$.

Islamic banking whether it is micro-finance is expanding fast. One author remembered that:

"Just look at the mathematics. Islamic finance is growing 50 per cent faster than the traditional banking sector, and it has huge growth potential. A quarter of the world's population is Muslim but only 1 per cent of the world's financial assets are sharia-compliant. Across the Middle East and North Africa, less than 20 per cent of adults have a formal bank account. That gap presents a huge economic opportunity for the UK" 5 .

\section{Overview of the Problem}

A tailor made concepts: Is Islamic banking a tailor-made concept? Having explained the main legal concepts of Islamic law, banking and finance through shar'iah law it is important to know how Islamic banking and its concepts are perceived worldwide coupled with a constant and persistent question: would Islamic banking be

\footnotetext{
4 Muhammad Zubair Mughal. Site: http://www.dailynewsegypt.com/2013/09/08/a-big-question-mark-on-the-islamic-financeindustry/

${ }^{5}$ George Osborne. Site: http://www.ft.com/intl/cms/s/0/42766334-3fc2-11e3-a890-00144feabdc0.html\#axzz2jIqgdtKy
} 
able to grow and expand in non-Islamic countries, in the interest of SMEs and entrepreneurs, where conventional banks are deeply rooted but is more and more reluctant to give loans? Islamic banking has been very fruitful in many Islamic countries but there some obstacles to Islamic banking and some legal concepts of sha'ria law are still either misunderstood or unknown in most (non-Islamic) countries. Islamic banks provide various contracts for entrepreneurs without interest with a profit-sharing devise instead. Shar'ia law remains inevitably the main source of Islamic law and it is strictly applied in Islamic banking law and all Islamic contracts such as, inter alia, ijara, mudabara and musarakha (infra) for instance. Today, all these legal and social contracts are pillars of Islam generating trillion of USD worldwide.

Some major obstacles to Islamic Banking: Driving force in some sectors (business and transactions) of emerging economies (Malaysia with the Bank Islam Malaysia Berhad, Dubai with its Dubai Islamic Bank, Egypt and Sudan with Faisal Islamic Bank, Indonesia, Pakistan) small and medium enterprises create jobs and employment (Table 1) contributing to the national Gross Domestic Products (up to 37\% of the Mauritian GDP).

Table 1: Distribution (\%) of employed persons by employment status and sex, 2011

\begin{tabular}{lll}
\hline Employment Status & Male & Female \\
\hline Employer & 5.3 & 1.6 \\
Own account worker & 15.7 & 9.1 \\
Employee & 78.3 & 85.1 \\
Contributing family worker & 0.7 & 4.3 \\
Total & 100.0 & 100.0 \\
\hline
\end{tabular}

Source: CSO

This paradigm shift is also applicable in non-Islamic countries (Islamic Bank international of Denmark, The Islamic Bank of Britain in the UK, Luxembourg with the Islamic Holdings System of Luxembourg, Australia, Netherlands, Hong-Kong) but is still unpopular in many countries (Mauritius, India, South Africa). Religion and language barrier, credit risk, benchmark risk, liquidity risk, operational risk, legal risk, withdrawal may account for this. Despite Islamic finance market has grown from 10\% to $15 \%$ major obstacles persist worldwide. In some non-Islamic countries (Mauritius, India). Refer to Chart 1 (Source: AlBaraka ${ }^{6}$ ) below which explains some major distinctions/differences (infra) between the two types of banking. Islamic banking is at its burgeoning stage in most non-Islamic countries including Mauritius. Any institution which is governed by shar'ia law and in the same way any Islamic institutions should depart from their conventional counterparts but would non-Islamic countries accept it? As there are both shar'ia law and Islamic finance is Islamic banking and entrepreneurship closely associated and/or to what extent they are performant? Islamic banking is growing at a rate of $10-15 \%$ per annum and there are over 200 Islamic banks operating in 65 countries with a population of around 1.3 billion, Islamic banks' capital is USD 90 billion that is growing at the rate of 15\% per annum (Pakistan Legal Decisions, 1992). These figures are not denied but apart from harmonization of Islamic law with domestic law there are some problems which may appear when a nonIslamic country (Mauritius, India, South Africa, England) wish to settle Islamic banks on its land. In Mauritius, the chronologies of events in the institutionalization of Islamic banking are as follows:

- 1998- Al Barakah Multi-purpose Co-operative Society Limited

- 1999- ALEEF incorporation

- 2005- Inaugural of Mauritius Islamic Finance Forum (MIFF) by the Islamic Cultural Centre

- 2005- Established of an Islamic Financial Services Committee run by the BOM ${ }^{7}$

- 2007-BOM entered in Associate Membership with IFSB ${ }^{8}$

- 2007-Amendment of the Banking Act

- 2008- BAI ${ }^{9}$ Takaful inauguration. Islamic banking week

\footnotetext{
${ }^{6} \mathrm{http}: / / \mathrm{www} \cdot$ albaraka.com/default.asp?action=article $\& \mathrm{id}=46$

${ }^{7}$ Bank of Mauritius

${ }^{8}$ International Financial Services Board.
} 
- 2008- Deliverance of Budgetary Speech to use Sukuk $k^{10}$

- 2008-Amendment of Public Debt Management Act

- 2008-BOM publication of the Guidelines for institutions conducting Islamic banking business

- 2009-Mauritius Leasing launched Ijarah ${ }^{11}$

- 2009- HSBC ${ }^{12}$ launched Amanah current and investment accounts

- 2009-FSC admittance as Associate member of IFSB

- 2009-Granting the first Islamic banking licence to Century banking Corporation

- 2010-Publication of SP5/10 on VAT by MRA for 'Murabahah ${ }^{13}$ 'dealings

- 2010-BOM admittance as a full member of IFSB

- 2010-BOM became founder member of IILM

- 2010-BOM and Bank Negera Malaysia entered in a Memorandum of Understanding (MoU)

- 2011-Al Barakah Multi-purpose Co-operative Society Limited with Al Huda Centre of Islamic Banking and Economics from Pakistan organized an "International Conference on Islamic Banking and Finance in Mauritius" on $5^{\text {th }}$ and $6^{\text {th }}$ April 2011 at Gold Crest Hotel, Quatre-Bornes, Mauritius.

Some pertinent legal issues: In Mauritius, the Bank of Mauritius has set Guidelines for Institutions conducting Islamic Banking Business. Very recently, the Kerala High Court, dismissing the petitions of Janata Party leader Subramanian Swamy and others against Al-Baraka Company, has ordered that companies which are registered under the tenets of shar'ia law to start operating a financial institution based on the principles of Islamic banking but through a separate legislation as the Banking Regulation Act provides for conventional banking which is also based on interest payment. Apart from shar'ia law, each and every Islamic country has its own Islamic Banking Act and Banking and Financial Institutions Act. In Arab-Malaysian Finance Berhard \& Ors v. Taman Ihsan Jaya Sdn Bhd \& Ors, the court was of the view that the sale of the properties between the bank and the customer was mala fide because the profits of Bai' muajjal (infra) contravened the Islamic Banking Act 1983, which prevails in Malaysia. In Arab-Malaysian Merchant Bank Berhad v. Silver Concept the Court held that Bai' muajjal were shariah compliant and that the sale was therefore bona fide between the bank and its customer. Whether developing or developed countries and standard of life is also different costs of doing business are relatively higher from one country to another. However, the main obstacle facing entrepreneurs is funding prior to start business and trade eventually, how to obtain it easily and without too much administrative hassle?

The concepts of Islamic Banking: Businessmen and investors are not always verse with sha'ria law. The concepts of Islamic banking in the management of the affairs of the company is strictly limited compared to conventional banks: though Islamic banks share the risk as partners projects of entrepreneurship are managed by the client and not buy the bank. Islamic banks exercise monitoring, follow-up supervision and have a right to check books and other administrative records. Islamic banks are also popular for lesser financial stress than conventional banking. Indeed, since they are partners in mudaraba or musharaka contracts they are also conceived as financial intermediary mobilizing savings from the public and they may advance capital to entrepreneurs readily than any conventional bank. Islamic banks and modes of financing apply to all religions but commercial banking system is contrary to shar'ia law and its different sources (hadiths, sunna, ijdma numa, fiqh). In non-Islamic countries there are national policies and strategies to develop Islamic banking. However, Islamic finance is open to any entrepreneur even if they are not of Islamic

\footnotetext{
${ }^{9}$ British American Insurance

${ }^{10}$ Sukuk (Islamic bonds) or securitized credit finance is the most dynamic instrument for capital mobilisation and has the same financial characteristics as conventional bonds and notes but the only difference is that all legal contracts must have been approved by sha'riah law.

${ }^{11}$ Ijara (or leasing) in Islamic law requires any Islamic bank (as lessor) to purchase the property of a person (homeowner or lessee) who will reside as a tenant over a specific period of time. He pays a fixed rent until he owns the asset. Ijarah is similar to conventional leasing with a lessor and lessee but the only difference with Islamic law or Sha'ria is that any Islamic bank may sell back the property at its original purchase price rather than its market value at the time of the sale.

${ }_{12}^{12}$ Hong Kong and Shanghai Banking Corporation

${ }^{13}$ Murabahah (or cost-plus) in Islamic law requires an Islamic bank to purchase commodities and to sell them at a predefined mark-up price. The client signs a 'promise to purchase' agreement with the bank before the latter purchases the property but the Islamic institution cannot earn excessive profits from the client. In the UK, Natwest has launched the Alif Baa Taa, a commercial finance based on Murabaha along with the Bank of Ireland.
} 
faith or do not abide to the teaching of the Qur'an. Islamic banks are certainly not religious institutions. All what they do or perform as partners (supra) are that their clients and themselves abide to Islamic law without being a Muslim or not. Thus, there is 'islamicity' of banking and not 'islamicity' of entrepreneurs such that obligations and restrictions in shar'ia law are to be applied/interpreted stricto sensu with respect to:

- Prohibition of illegal activities (haram)

- Prohibition of games of chance (maysir)

- Prohibition of interest (riba)

- Prohibition of speculations and chance (gharar)

- Payment of Islamic tax (zakat)

- Acceptance and obligations of mudabara of profit-sharing contracts

- Acceptance and obligations to musharaka or partnership contracts

- Acceptance to shar'ia compliance

- Acceptance of savings, investment and zakat accounts

This list is certainly not exhaustive. There are indeed other obligations such as acceptance of safe keeping (wadiah) and Islamic bonds (sukuks). Another non-negligible issue is that non-Islamic countries are often scared of Islamic banking and it may be three-fold: first conventional banks are afraid that Islamic banks may capture most niches, second they may disappear and third there is too much Islamicity. Indeed, in most countries where Islamic banks have flourished shar'ia law must prevail and strong financial institutions (Islamic Development Bank, Financial Service board, International Association of Islamic banks) must be set up urgently to cope with Islamic finance.

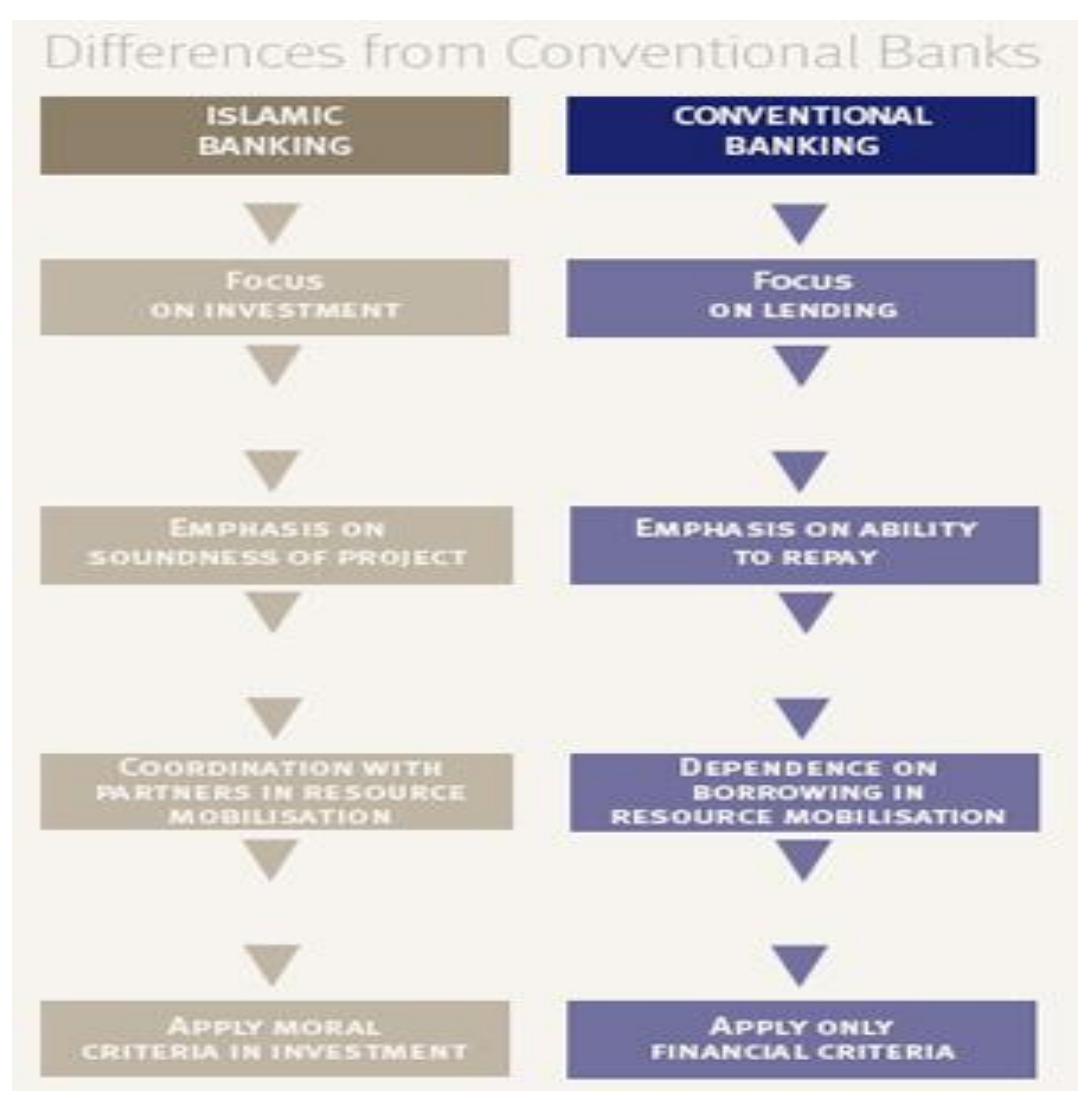

\section{Methodology}

The Mauritian experience is examined in the wider global context using a 20-year secondary data series over the period 1990-2012 periods, obtained from various sources. From information gathered from the Holy 
Quran, books, reports, websites ${ }^{14}$ it is possible to explain both the ideology of entrepreneurship and the techniques of fundings in Islamic banking.

\section{Results and Discussion}

The ideology of entrepreneurship in Islamic banking: Islamic banks become an entrepreneur when they receive funds from depositors and as financiers (or a two-tiered mudaraba system where they act both as client or mudarib and owner of capital or rubbul-mal) when they provide funds to local entrepreneurs. However, over and above all Islamic banking provides funds relatively more easily than traditional banks do to local and young entrepreneurs because they themselves rely on transactional deposits and investment deposits provided of course there are no economic activities or speculations (ghirar), entrepreneurs accept an Islamic tax (zakat) and they prohibit the production of goods and services which are prohibited in Islamic law, customs and traditions (haram) or which go outside Islamic concept and patterns. Islamic banks do not interfere in the management of the company but has the right to determine the kind of activities and its locations, its duration of course and monitor the investments. In contrast with conventional banks which impose guarantees such as security to ensure its capital Islamic banking, on the other side, have a good reputation not to interfere with the management of the investment or anything which may eventually harms the performance of the entrepreneur (mudaraba). Nonetheless, Islamic banks have a right to check records and books, monitoring and regular supervision but entrepreneurs remain fully independent in conducting the affairs of their company or business. In return, it is implied that Islamic banks become a true partner in the process and the entrepreneur is under the obligation to share the net profit (mudharaba) under pre-agreed terms and conditions once all administrative costs, capital depreciation or Islamic tax have been deducted, and may even pay a salary to the entrepreneur in a win-win situation. In any event there are losses they shall be borne by the lender or capital provider. The entrepreneur shall lose time and effort invested in the enterprise, business and trade but at least he will bear no loss as he would have been in conventional banking where he may lose all his assets after his property has been mortgaged to pay back the loan with heavy interests.

The techniques of funding for entrepreneurs based on shar'ia contracts: Mudaraba remains the main conduit for the outflow of funds from bank. Practically the same conditions apply to musharaka financing, which is a sort of joint venture, to the exception that profits and losses are borne proportionally to the capital contributed on agreed ratio. The bank may provide managerial expertise but each Islamic bank may have its own Shariah Advisory Council with a view to harmonize Islamic law, rules and principles. If mudharaba and musharaka remain eventually the strong pillars of Islamic banking they remain undeniably the two main profit-sharing arrangements, but central to the nervous system is the Shar'ia Supervisory Board whose report shall tally with that of the management of the bank which shall be in strict compliance with shar'ia law. In practice, however, Islamic banks provide various financial facilities and which might, in addition to mudaraba and musharaka contracts; constitute other means of funds for young entrepreneurs. Table 1 reflects the types of Islamic contracts afforded by Islamic law \& Its importance for entrepreneurs:

Bai'muajjal/Bai-Bithaman Ajil 0 and resale of properties on a deferred payment with a profit margin

Bai'salam $\Longrightarrow$ Also known as prepaid purchase. In fact, Islamic banks give the goods first and receive the money later

Ijara $\longrightarrow$ Also known as leasing where Islamic banks purchase equipments and lease them to their clients who may opt to purchase them after monthly payments. This type of Islamic funding is useful for young entrepreneurs who can't afford to purchase costly equipments and materials prior to begin business Istissanaq Islamic banks will purchase the goods from the manufacturer on behalf of a third party but the goods will be produced and delivered at a later date

Qard hasan $\longrightarrow$ Islamic banks may give loans as well but they must be available to needy people. In return, they will repay back the loan but they may add a margin if they wish (discretion)

\footnotetext{
${ }^{14}$ Central Statistics Office CSO Survey 2007
} 
Murabaha wamic banks will purchase the commodities for its client but would add a mark-up (or profit margin) agreed by the parties before reselling them on a cost-plus basis profit contract.

Salarh In this type of contract Islamic banks make a full payment of a specified commodity not available with the seller, which is to be delivered on a specified future date in specified quantity and quality SukuR Is a certificate which represents the holder's proportionate ownership in an undivided part of an underlying asset where the holder assumes all rights and obligations to such asset

Takaful is an insurance contract where a group of persons agree to share a certain risk by collecting a specified sum from each person and in case of loss to any one of the group, the loss is met from the collected funds

(Table 2. Source: author)

Some facts and figures: Despite SMEs are still relying on traditional banks (Rs 1.7 billion has been approved by the Bank of Mauritius to finance entrepreneurs in Mauritius after the setting up of the Small and Medium Development Authority) in Mauritius as a Welfare State (education, health and transport is free) application of interest-free financing has gained a remarkable success worldwide. In 2011, small businesses accounted for $45 \%$ of total employment against 32\% in 1990. (Chart 2 - Employment by occupational group and sex in Government Services, 2011. Source: CSO)There are actually 176-180 financial institutions spread world-wide but most of them are located in Muslim countries and they continue to spread from one continent to another (the Middle East, North Africa, Southeast Asia, Sub-Saharan Africa, Central Asia, Western Europe, England, USA, South Africa and even in small development island States (Mauritius, Maldives, Comoros). Refer to Figure 1 and Figure (below) refer to unemployment and employment rate in Mauritius.

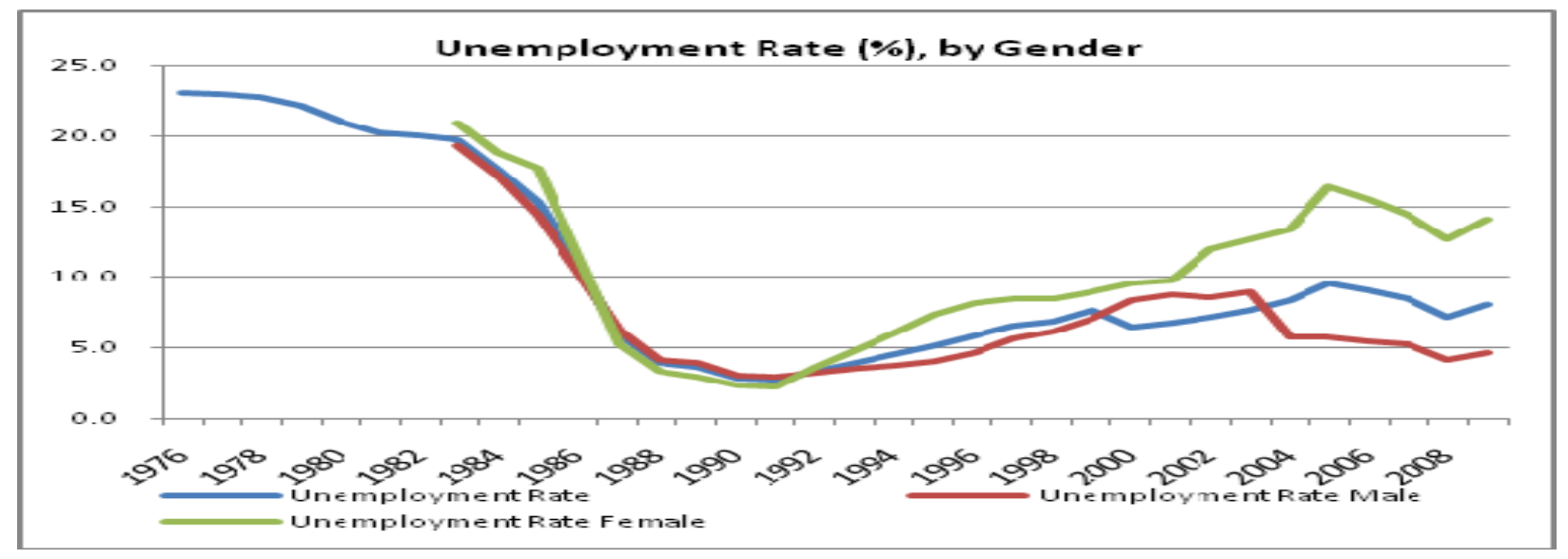

Legislators, senior officials \&..

Professionals

Technicians \& associate.

Clerks

Service workers

Skilled agricultural \& fishery.

Craft \& related trade workers

Plant \& machine operators

Elementary occupations

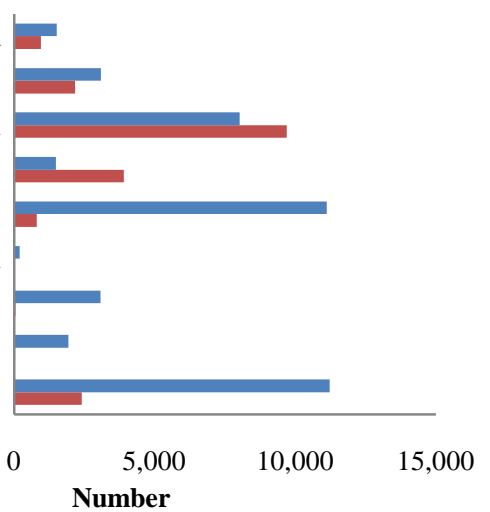

Male 
Figure 3: Global sukkuk issuance

Global sukuk issuance

Sbn

By country, 2011, \$bn

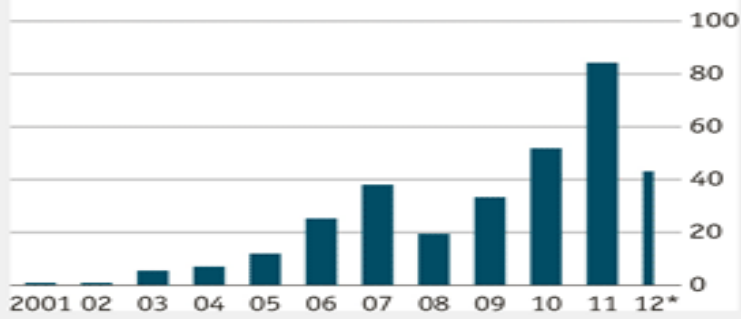

Malaysia 58.1

Qatar 9.3

Sources: Zawya Sukuk Monitor; Islamic Financial Information Service

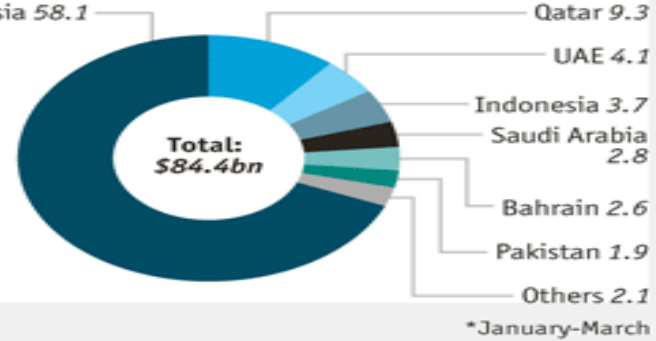

Source: Islamic Financial Information Service

\section{Figure 4: Muslim population in Africa and Islamic Finance}

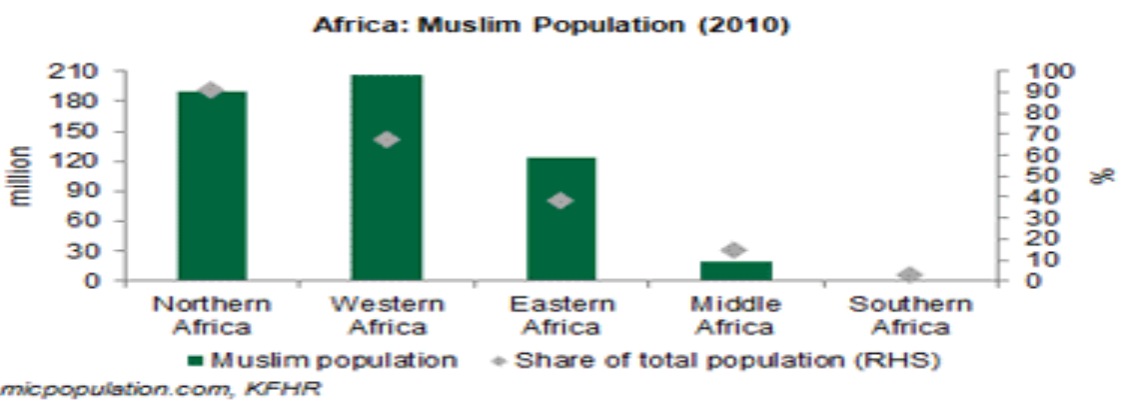

Source: www is lamicpopulation com, KFHR

Distribution of the African Population by Classes

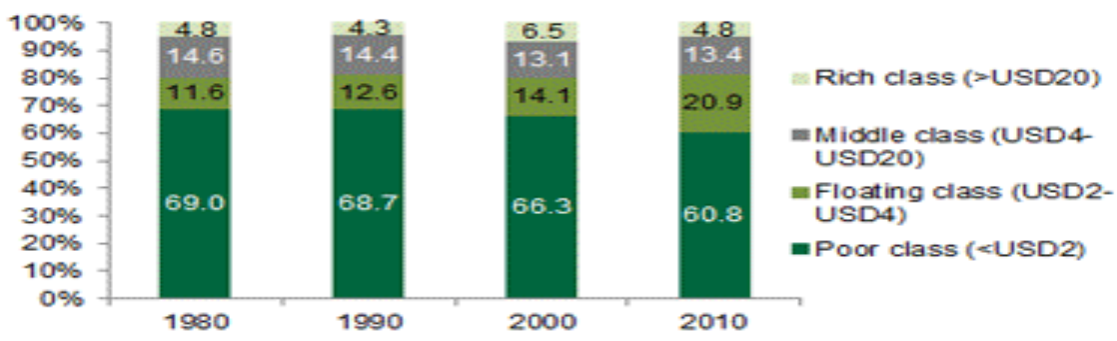

Source: $A F D B, K F H R$

Africa: Opportunities for Islamic Finance

\begin{tabular}{|c|c|}
\hline Karket player & Opportunities \\
\hline $\begin{array}{l}\text { Foreign Islamic } \\
\text { financial institutions }\end{array}$ & $\begin{array}{l}\text { - Foreign Islamic financial institutions (full-fledged and Islamic windows) to } \\
\text { establish Islamic banking and takaful operations in Africa. }\end{array}$ \\
\hline Foreign investors & $\begin{array}{l}\text { - Overseas Shariah investors investing in African assets and businesses and } \\
\text { tapping into new funding sources through funds and sukuk issues. }\end{array}$ \\
\hline Local banks & $\begin{array}{l}\text { - African-based banks providing a range of Shariah-compliant investment and } \\
\text { financing products and services to corporations, institutions and high net worth } \\
\text { individuals in the region. }\end{array}$ \\
\hline Fund managers & $\begin{array}{l}\text { - Establishing Shariah-compliant funds as well as alternative asset classes such } \\
\text { as commodity and infrastructure. }\end{array}$ \\
\hline Local exchanges & $\begin{array}{l}\text { - Providing an Islamic listings platform for domestic and international issuers of } \\
\text { Shariah-compliant instruments. }\end{array}$ \\
\hline $\begin{array}{l}\text { Local financial } \\
\text { institutions }\end{array}$ & $\begin{array}{l}\text { - Provision by African-based financial institutions of Shariah-compliant/ ethical } \\
\text { financial services and products to Muslim and non-Muslim customers in Africa. }\end{array}$ \\
\hline
\end{tabular}

Source: African Development Bank. 1980-2010 
Last year (2011-2012) Century Banking Corporation became the first Islamic bank in Mauritius after it has received accreditation from the Bank of Mauritius. Mauritius has signed Double Tax Avoidance Agreements with 33 countries and it may encourage Islamic countries to choose Mauritius as a better destination for their investment projects. In some way or another return on assets and return on equities for Islamic banks were $2.3 \%$ and $22.6 \%$ compared with $1.35 \%$ and $15 \%$ for the conventional banks (Iqbal, 2000). And that countries with larger financial systems need, else being equal to grow faster (King and Levine, 1993). By 2015, half of the savings of the world's estimated 1.2-1.6 billion Muslims will be in Islamic financial institutions (International Organization of Securities Commissions). Only the total assets of Islamic banks account to USD 155 billion in 1994. Islamic finance industry will be valued at USD 2 trillion in the next five years and its assets are worth USD 895 billion It is also important to conclude by laying emphasis on financial crisis and its impacts on conventional banks while Islamic finance is flourishing non-stop in a world which is now dominated by globalization, poverty and famine, natural disasters, unfair competition (intellectual property rights) and it now important for entrepreneurs to think twice before having a loan from traditional banks (refer to Figure 3 and Figure 4). Islamic banking is now a blooming industry in most Islamic countries where they have achieved recognition and respect. Microfinance has been so successful in Bangladesh, Malaysia and even Singapore and there is no reason why non-Islamic countries might not take benefits of all facilities.

\section{Conclusion and Recommendations}

Islamic banking could be the golden age for entrepreneurs and SMEs unless governments find policies to encourage conventional banks to give loans to finance entrepreneurs and SMEs in the form of micro-credits. The Mauritian government has passed several legislations ${ }^{15}$ to encourage the development of SMEs in Mauritius. They contribute to 37\% (120 billion rupees) of the GDP, employing more than some 250,000 people and they are still mushrooming on the island. Government policies and loans (Rs 50,000), provided they have innovative proposals, with low interests from conventional banks (SMEs) may account for this. Since Islamic banking is at its burgeoning stage in Mauritius, and in many non-Islamic countries as well, there are hope and expectations that there shall be a real departure from conventional bank to Islamic banking soon. Non-Islamic countries shall legislate by passing appropriate law on Islamic banking in addition to various sources of Islamic law. Like in Mauritius, non-Islamic countries must allow Islamic banks to settle in their countries in accordance with sha'ria compliance creating jobs and employment (infra). In return, they would probably attract Foreign Direct Investment (FDI) as well as this reflects to what extent Mauritius has more than 30 double taxation avoidance agreement (DTAA) attracting billion of dollars encouraging foreign investors to invest in Mauritius in various emerging sectors (tourism and hotels, buildings and luxurious apartments).

\section{References}

Abou-Gabal, K. \& Klinger, F. (2011). Islamic Finance and Entrepreneurship; Challenges and Opportunities Ahead, Harvard Kennedy School in cooperation with The Kuwait Foundation for the Advancement of Sciences.

Ahmad, A. (2000). Instrument of regulation and control of Islamic banks by the central bank, Islamic Research and Training Institute, Research Paper No. 10

Asyraf, W. D. (2011). Ethical and Social Responsibility models for Islamic Finance International Shar'ia Research Academy for Islamic Finance (ISRA)

Bank of Mauritius. (2008). Guideline for institutions conducting Islamic Banking business, June 2008

Chapra, M. U. (1982). Money and banking in an Islam economy: Monetary and fiscal policy of Islam, International Centre for Research in Islamic Economics, Jeddah

Chapra, M. U. (1985). Towards a just monetary system, The Islamic Foundation, UK

Čihák, M. \& Hesse, H. (2008). Islamic Banks and Financial Stability: An Empirical Analysis. IMF Working Paper No. 08/16. Washington: International Monetary Fund.

\footnotetext{
${ }^{15}$ Labour Act, Renumeration Orders, Companies Act, SMEDA Act, Business Facilitation Act, Business Registration Act Local Govt Act , Employment Relations Act
} 
Iqbal, M. (2000). Islamic and commercial banking in the nineties: a comparative study in the proceedings of the Fourth International Conference on Islamic Economies and Banking. Loughborough University, August 13-15, pp.409-431

Iqbal Z. \& Mirakhor, A. (1986). Islamic banking, IMF, Washington DC

Iqbal, M. \& Molyneux, K. (2005). Thirty years of Islamic Banking: History, Performance and Prospects, Palgrave Macmillan

Imam, P. \& Kpodar, K. (2010). Islamic Banking: How Has It Diffused? IMF Working Paper No. 10/195. Washington: International Monetary Fund.

Janachi, L. (1995). Islamic Banking, Concepts, Practice and Future, 2nd Edition. Manama: Bahrain Islamic Bank.

Khan, M. S. \& Mirakhor, L. (1985). The financial system and monetary policy in an Islamic economy, unpublished IMF paper

Kuran T. (2008). The scale of entrepreneurship in middle eastern history: inhibitive roles of Islamic institutions, ERID Working Paper Number 10, Duke University, Economic Research Initiatives at Duke working Papers Series, March 2008

Khan, M. S. \& Mirakhor, P. (1987). The Framework and Practice of Islamic Banking, Theoretical Studies in Islamic Banking and Finance, IRIS Book, USA, pp.1-13.

Pakistan Legal Decisions. (1992). Federal Sharait Court Judgment on Interest, Lahore PLD Purchasers. 